\title{
CORPO COMO ÂNCORA DE SENTIDOS E PRODUTQR DE SIGNIFICADOS: TENSOESS A PARTIR DA PERFORMANCE ART
}

\author{
THE BODY AS ANCHOR OF SENSES AND PRODUCER OF MEANINGS: \\ TENSIONS FROM PERFORMANCE ART \\ CUERPO COMO ANCLA DE SENTIDOS Y PRODUCTOR DE SIGNIFICADOS: \\ TENSIONES A PARTIR DEL ARTE DE PERFORMANCE
}

Jéssica Vitorino da Silva Terra Nova*

vitorino.jessica@gmail.com

Fabio Zoboli**

zobolito@gmail.com

\begin{abstract}
REVISTA PEDAGÓGICA
Revista do Programa de Pós-graduação em Educação da Unochapecó | ISSN 1984-1566

Universidade Comunitária da Região de Chapecó | Chapecó-SC, Brasil Como referenciar este artigo: TERRA NOVA, J. V. da S.; ZOBOLI, F. Corpo como âncora de sentidos e produtor de significados: tensões a partir da performance art. Revista Pedagógica, Chapecó, v. 18, n. 39, p. 241-263, set./dez. 2016. DOI: http://dx.doi.org/10.22196/rp.v18i39.3624
\end{abstract}

RESUMO: O presente ensaio pretende revisar e argumentar - sob a perspectiva de alguns aspectos da semiótica e da fenomenologia - a crença de que o corpo é central na experimentação do conhecimento. Para tal, faremos uso da Performance Art como instrumento de organização sígnica que opera por intermédio do corpo de um performer que organiza signos com a intensão de propor uma experiência. O texto é fragmento do referencial teórico de uma dissertação de mestrado intitulada "A Performance Art como propedêutica da experiência: construção de sentidos e significados sobre, com e por meio do corpo". O ensaio insiste na ênfase da necessidade da utilização da Performance Art como forma possível de estruturar e determinar a experiência do sujeito frente a um objeto a ser conhecido no âmbito das práticas pedagógicas de mediação de conhecimento.

Palavras-Chave: Corpo. Sentido. Performance Art. Arte. Educação.

ABSTRACT: This paper aims to review and argue from the perspective of some aspects of semiotics and phenomenology - the belief that the body is central in the trial of knowledge. For this end, we will make use of Performance Art as a signic organization tool that operates through the body of a performer that organizes signs with the intention of proposing an experience. The text is a fragment of the theoretical framework of a master's dissertation entitled "A Performance Art como propedêutica da experiência: construção de sentidos e significados sobre, com e por meio do corpo" (Performance Art as propaedeutics of experience: construction of senses and meanings of, with and through the body). The test insists on the emphasis of the need for the use of Performance Art as a possible way to structure and determine the experience of the subject when facing an object to be known within the pedagogical practices of knowledge mediation.

Keywords: Body. Sense. Performance Art. Art. Education.

RESUMEN: Este trabajo tiene como objetivo revisar y discutir - desde la perspectiva de algunos aspectos de la semiótica y la fenomenología - la creencia de que el cuerpo es central en el proceso de conocimiento. Con este fin, vamos a hacer uso de la performance como herramienta de organización sígnica que opera a través del cuerpo de un artista que organiza signos con la intención de proponer una experiencia. El texto es un fragmento del marco teórico de la tesis de maestría titulada "A Performance Art como propedêutica da experiência: construção de sentidos e significados sobre, com e por meio do corpo" (El arte de Performance como propedéutica de la experiencia: la construcción de sentidos y significados en, con ya través del cuerpo). Lo estudio hace hincapié en la importancia de la necesidad de la utilización de la performance como una posible manera de estructurar y determinar la experiencia del sujeto frente a un objeto a ser conocido dentro de las prácticas pedagógicas de la mediación del conocimiento.

Palabras clave: Cuerpo. Sentido. El arte de Performance. Arte. Educación 


\footnotetext{
* Universidade Estadual da Bahia/UNEB Campus Jacobina. Mestre em Educação Pela Universidade Federal de Sergipe - UFS. Professora substituta do Departamento de Educação Física da Universidade Estadual da Bahia/UNEB Campus Jacobina.

${ }^{* *}$ Universidade Federal de Sergipe - UFS Professor do Departamento de Educação Física da Universidade Federal de Sergipe - UFS. Professor do programa de pós-graduação em Educação (PPGED) e do programa de pós-graduação em cinema (PPGCINE). Doutor em Educação pela Universidade Federal da Bahia - UFBA. Membro do grupo de pesquisa "corpo e governabilidade".
}

\section{INTRODUÇÃO}

É de saber que, a Educação esteve historicamente presa a uma significação epistemológica de ser humano e consequentemente de corpo - própria da concepção de homem cartesiana a qual absorve a força da racionalidade científica, da objetivação e da homogeneização para a base das culminâncias filosóficas. A educação, sob esta concepção, fica reduzida ao processamento simplista de transmissão de conhecimentos, com valoração superior da 'inteligência mental' que fragiliza e desfavorece uma cultura fundada no 'corpóreo'. Ou seja, as experiências corporais na educação sempre foram concebidas em detrimento às faculdades mentais.

Sob tais prerrogativas, há a constante necessidade de buscar, criar e propor outras formas de ser e de atribuir sentidos à materialidade do corpo em que a relação com o mundo e a cultura, dentre outras possibilidades, sejam interpostas como resposta às novas situações. Acolher as experiências corporais no sentido da aprendizagem é caminho necessário para a proposição de novas formas e propostas legítimas onde a atenção e a atuação do corpo - que não é coisa nem ideia, mas movimento, expressão criativa e sensibilidade (NÓBREGA, 2000) - devem ser oportunos em sala de aula. Neste sentido, deve-se imperativamente "insistir no aculturamento em que o corpo possa ser mediador da aprendizagem, em que ele seja ferramenta vivencial da apropriação do conhecimento" (ZOBOLI, 2012, p. 150).

Compreende-se que a vivência do saber, a experiência está diretamente ligada aos processos de significação intrinsecamente associados a produção de sentidos. Acredita-se que o sentido é antes construído no e por intermédio do corpo na condição mais elementar e imediata da experiência, sob o nível das sensações. A significação aqui não pode ser compreendida simplesmente como um ato de pensamento - restrito a mente e ao cérebro -, ao cogito de Descartes, mas como "a experiência do corpo ao nos fazer reconhecer uma imposição do sentido que não é aderente a certos conteúdos. Meu corpo é esse núcleo significativo que se comporta como uma função geral" (MERLEAU-PONTY, 1999, p. 203).

A experiência é o processo dado desde o contato sensorial imediato daquilo que se apresenta ao contato com uma fonte cognitiva de informações denominada de faculdades mentais (percepção, memória, imaginação, introspecção). A partir de Salatiel (2006) é possível afirmar que para Kant, filósofo alemão, a experiência envolve duas categorias os quais ele denomina de faculdades do conhecimento ou faculdades de determinação do objeto a ser conhecido: 1) "Sensibilidade" - contato direto que ele denomina de intuições que implica necessariamente a noção de tempo e espaço - noção sensível dada a priori; e 2) "Entendimento" - distribuição/enquadramento, como "uma 
tábua de classificação", do que foi captado pela sensibilidade da razão dando atribuições de qualidade ao objeto. Essas duas faculdades são condições necessárias para que ocorra a experiência, trata-se do processo que confere sentido a um objeto tornando-o cognoscível.

Em Peirce (1999), a experiência pode ser dividida em três níveis: 1) "Sensação" - Relação elementar e imediata do corpo com o mundo ou objeto; 2) "Percepção" - Provoca um raciocínio gerado a partir da sensação primeira que em contato com a mente ligou-se a um signo já presente nesta; e 3) "Compreensão" - Estabelece novas relações com a realidade criando um novo signo. Assim, explicita o filósofo que, a experiência corporal humana tende a gerar na mente um resultado cognitivo ou raciocínio a partir de uma porção de signos.

A partir das preposições sintéticas acerca dos filosófos Kant e Peirce, feitas a partir de Salatiel (2006), é necessário frisar que o conceito de experiência está intrinsecamente relacionado ao ato de conhecer ou da constituição do pensamento que, embora ligada a concretude do "mental" implica a coparticipação do "corporal", essencial na constituição da experiência. . Entretanto, Kant na defesa das funções lógicas do pensamento, onde a experiência é determinada pelas categorias, conceitos a priori (a priori: que antecede a experiência) pelos quais é possível reduzir um múltiplo de sensações desordenadas da experiência a uma unidade inteligível, permitindo assim o conhecimento e Peirce que sob maior influência kantiana, na cosmologia evolucionária, com base na semiótica, descentraliza a estrutura lógica do conhecimento.

Sistemas e operadores classificam, organizam os signos e conferem sentidos a estes tornando possível a experiência. Os signos são produzidos na mente de modo a participar da composição de raciocínios e constantemente formados de forma progressiva. Neste sentido, considera-se que o ato de aprender ou a produção de conhecimento é sempre decorrente de uma produção de signos que se ligam na incessante busca de sentido. Em outras palavras, aprender (significar) é percepção, associação/organização e interpretação destes (símbolos/significantes).

Inseridos em tais assertivas, o presente ensaio pretende argumentar a crença de que o lugar do conhecimento é no corpo do indivíduo, ou seja, a extensão cognitiva do sujeito se constrói sempre sobre este substrato corporal, através da experiência e da linguagem. Almeja-se ainda discorrer acerca da Performance Art como instrumento de organização sígnica que opera por intermédio do corpo a construção de um discurso, de uma representação. O performer, por sua vez, é compreendido como uma espécie de semiólogo que utiliza intencionalmente seu corpo para manipular signos que são oferecidos a fim de propor uma forma de experiência - provocar um conhecimento.

O ser humano existe via corpo. O corpo é o meio pelo qual o ser humano experimenta o mundo. O sentir, o 
pensar e o agir caracterizam a existência humana. A estrutura biológica do ser humano permite o sentir, pensar e agir; no entanto, esse sentir, pensar e agir são mediados por uma infinidade de signos sociais, são formatados pela dimensão da cultura. É no corpo que se ancoram os sentidos, "mesmo os símbolos da ciência não podem existir e dizer algo sem a dimensão da experiência corporal" (MERLEAU-PONTY, 1999, p. 3).

A partir da problemática e das argumentações expostas sinteticamente nas palavras introdutórias do texto, o presente ensaio disserta sobre o corpo como vetor de sentido e significado propondo a Performance Art como ferramenta para significar conhecimento. Assim, o ensaio foi dividido em duas sessões: na primeira parte é argumentada - sob a perspectiva de alguns aspectos da semiótica e da fenomenologia - que a crença de que o lugar do conhecimento é no corpo do indivíduo, ou seja, a extensão cognitiva do sujeito se constrói sempre sobre este substrato corporal, através da experiência e da linguagem. Na segunda e última parte do ensaio a Performance Art como instrumento de organização sígnica que opera por intermédio do corpo de um performer que organiza signos com a intensão de propor uma experiência.

\section{CORPO COMO ÂNCORA DE SENTIDOS E PRODUTOR DE SIGNIFICAÇÕES}

Não há pensamento que não comece pelo corpo tal como não há sentido que não comece pelo corpo mas, igualmente, não há corpo que não seja pensado tal como não há corpo que não seja sentido. Interrogarmos os modelos do sentir e do pensar que fazem o corpo é uma forma de esclarecer o que do corpo é capturado e o que do corpo é incapturável em cada exercício de poder que sobre ele se exerce. É uma forma, enfim, de a ele nos dirigirmos. Oxalá o nosso apelo seja acolhido.

Bártolo (2007)

Temos visto que a complexidade firmada no contexto da experiência sobressalta algumas faculdades, ou seja, níveis pelos quais apontam a importância primeira do corpo como suporte das relações entre o homem e o mundo. Os procedimentos sensitivos e perceptivos são tragados primariamente para que então o entendimento, pelo nível da razão, atribua qualidades que conferem a compreensão sobre determinado objeto ou fenômeno, ou a constituição de um pensamento.

No campo da Educação, os aspectos lógicos relacionados ao processo de construção de conhecimento sobre o corpo, bem como algumas de suas bases epistemológicas (tradicionais) precisam ser superadas a fim de suscitar 
atitudes e hábitos um tanto mais significativos na relação de aprender/conhecer, no processo de produção de sentidos e significados através do corpo.

Duarte Júnior (1981, p. 13) afirma que "não há conhecimento sem símbolos". Ora, os símbolos possuem uma capacidade abstrativa que nos permitem conferir transferências constantes de experiências anteriores para outros "novos" contextos, ou seja, através do ato de simbolizar podemos agir em novas situações com base em experiências passadas, isto porque somos capazes de abstrair dos símbolos conferidos pela experiência os seus significados. Neste sentido, reitera-se que "ao aprender, estamos criando um esquema de significados que permite interpretar nossa situação e desenvolver nossa ação numa certa direção" (DUARTE JÚNIOR, 1981, p. 14). "Aprender é um processo que mobiliza tantos os significados, os símbolos, quanto os sentimentos, as experiências a que eles se referem" (DUARTE JÚNIOR, 1981, p. 25).

Os símbolos - signos já "cristalizados" no âmbito da cultura mesmo que temporariamente - são, portanto, considerados padrões de significados que permitem a comunicação (com-partilhamento) entre os seres humanos. Ora, bem sabemos que a consciência e a razão humana, nascem e se constituem com um aparato pelo qual se denomina "linguagem". De acordo com Betti (2007), a linguagem humana não se restringe à sua dimensão linguística - a língua portuguesa falada e escrita, por exemplo, - mas, é entendida como capacidade de produzir informação/conhecimento. Assim, como não há produção de informação/conhecimento senão por intermédio de signos (qualquer fenômeno dotado de sentido/significação), pode-se compreender a linguagem como a capacidade de produzir signos de qualquer espécie, sejam sonoros, visuais, táteis etc. Neste sentido, enfatiza o autor que, sob tais argumentos, a linguagem não pode e não deve ser considerada um produto acabado mas, um permanente processo de produções sígnicas.

Primeiramente, é importante lembrarmos que o signo, na menção de Peirce (1990, p.46): “[...] é aquilo que, sob certo aspecto ou modo, representa algo para alguém. Dirige-se a alguém, isto é, cria, na mente dessa pessoa, um signo equivalente, ou talvez um signo mais desenvolvido [...]". Frente a esse conceito de signo, consideramos necessário enfatizar uma característica do mesmo (talvez a mais importante): o signo tem o poder de representar seu objeto na subjetividade de uma pessoa. Neste sentido, ele só pode funcionar como signo se tiver esse poder de representar, substituir, de estar no lugar de algo (seu objeto) que seja diferente dele. Ou seja, o signo não é o objeto, ele é o outro, está apenas no lugar do objeto.

Assim, o signo só pode substituir o objeto de certo modo, numa certa capacidade, mas nunca por inteiro ou completamente, pois sua principal característica é a diferença e seu poder de representação (SANTAELLA, 2007). 
Além disso, em semiótica, considera-se que o signo é o único modo de um sujeito apreender a realidade objetiva em sua subjetividade. Ou seja, a realidade externa apenas pode ser pensada pela mente se, e somente se, ela for traduzida pela percepção e pela cognição na forma de signo, de modo que, quando presente na subjetividade, passa a se articular com outros signos, construindo redes de associação semiótica: argumentos. A formação da identidade cultural é constituída mediante a exposição do sujeito aos discursos e signos veiculados no tecido social, os quais, paulatinamente, são subjetivados e, dessa forma, passam a constituir seus pensamentos. A formação do sujeito, ou de sua identidade, acontece mediante o contexto cultural e simbólico com qual o mesmo está em contato e, nesse sentido, a experiência é a grande operadora desse processo.

Entender a formação do sujeito baseados na semiótica de Peirce, é compreender que as experiências vividas passam a ser experiências pretéritas, passando, portanto, a ser aquilo que já foi e não é mais; é outra coisa que tem o poder de representar, ou seja, é um signo com o poder de agir e operar na mente do sujeito. A experiência pretérita passa a ter um estatuto de alteridade para a consciência, formando assim um não-ego interno (IBRI, 1992). Esse estatuto de alteridade existe porque a experiência pretérita é algo distinto e exterior ao sujeito - sujeito este que já é formado por um ego. Ao passar por uma experiência, o sujeito não continua mais o mesmo, exatamente, porque a experiência deixa resultados na mente do mesmo, que passam a participar/interferir nas experiências presentes e futuras do sujeito.

Assim, "Para Peirce, a produção do conhecimento é sempre uma produção de signos - o pensamento é signo - e o significado de um signo é sempre um outro signo [...]” (BETTI, 2007, p. 203). É neste sentido que a semiótica peirciana entende que todo o processo de produção de signos (linguagem) é a raiz da produção do conhecimento, pois na medida em que a linguagem envolve processos e produtos, capacita produzir informações/conhecimentos, retomar experiências vividas em novas significações, perceber e atualizar novas possibilidades de ser e fazer.

A experiência - denominação que se refere à ação revelada pelo acesso da consciência ao conhecimento de objetos exteriores, situados "fora" de seus limites ou o inteiro resultado cognitivo do viver (PEIRCE, 1978) - trata-se de um processo pela qual advêm resultados cognitivos, em mobilização de signos e compreensão crítica das funções destes no mundo. Sendo assim, antes de se gerar um raciocínio, de se concretizar um pensamento ou compreender uma realidade/objeto é necessário atentar-se, desde outrora, a ocorrência do "colocar-se" em relação à situação que submerge entre relações estabelecidas entre o homem e o mundo. Esse envolvimento incluem percepções, estados afetivos, aspectos estes anteriores à significação ou concretização do pensamento que se repousam no corpo, no corporal. 
Para Bártolo (2007) os signos se inscrevem no corpo. O corpo é um espaço onde se ancoram os sentidos em realização constante de significações necessárias a vida. Para o autor, o corpo, embora, não sendo o próprio corpo por inteiro significável, acolhe códigos que nele se ancoram e ganha, assim, um estatuto de significante flutuante, ou seja, signo que vai ganhando sentido e sendo composto com o decorrer das análises realizadas. Entre a relação significante-significado, é evidente que "o corpo é, a um tempo, instrumento e espaço de comunicação e significação” (BÁRTOLO, 2007, p. 91). Assim, é possível conjecturar que, aprender (significar) é percepção, associação/organização e interpretação destes (símbolos/significantes). O lugar do conhecimento, portanto, é no corpo do indivíduo (ALVARES, 2012).

O corpo, qualquer corpo, poderá sempre ser tomado como tabula rasa, espaço de inscrição, espaço de marcação. Significar e marcar são gestos idênticos. Significar corresponde à imposição de um sentido. Os marcadores que definem um determinado espaço (seja esse espaço carne ou palavra, máquina ou pedaço de terra) marcam-no com o seu sentido mais forte o suplante (BÁRTOLO, 2007, p. 15).

Um corpo (ou corpos), que é instrumento, fruto de uma cultura, sobretudo dinâmica e em processo constante de construção, pode ser visto como um espaço aberto de inscrição de signos, de linguagem, de comunicação e significação. O corpo é da ordem da significação, afirma Bártolo (2007), não o corpo diminuto a conceitos ou do corpo massificado, opaco e hostil, objeto dos anatomistas, mas o corpo situado, aquele que se confunde com o sentimento da "substância da nossa presença", em constante relação de desejo, de interlocutividade, de intercorporeidade. É neste corpo onde se ancoram os sentidos, no corpo que "não se identifica com o meu corpo físico, com a minha carne, nem se assemelha ao corpo de uma coisa (uma cadeira, ou um tronco), antes é condição de possibilidade desses corpos, num certo sentido o seu corpus" (BÁRTOLO, 2007, p. 136). De acordo com Santa'Anna (1995), o corpo é um lugar de significações e incorporação de experiências e signos, "[...] corpo é uma palavra polissêmica, uma realidade multifacetada e, sobretudo, um objeto histórico" (p.19). Para Merleau-Ponty (1999), a significação não pode ser alcançada pelos meios naturais do corpo; é preciso então que ele se construa um instrumento e ele projete em torno de si um mundo cultural, simbólico.

A contribuição da semiótica para esta discussão, e que foi perspectivada por Betti (1994, p. 42 apud BETTI, 2007), é apontada no sentido de alertar que a Educação Física, de modo específico, não deve se transformar em um discurso sobre a cultura corporal de movimento, mas numa ação pedagógica com ela - na medida em que se 
entende que um saber orgânico não pode ser alcançado pelo puro pensamento ou que não é um saber que se esgota num discurso sobre o corpo/movimento, mas sim através da corporeidade impregnada, do sentir e do relacionar-se. Ou seja, "a dimensão cognitiva (crítica) [...] far-se-á sempre sobre este substrato corporal, mas só é possível através da linguagem" (BETTI, 1994, p. 42 apud BETTI, 2007, p. 208). Sendo assim, caberia (e cabe) não apenas a Educação Física, mas a educação de modo geral, o papel de auxiliar na mediação simbólica desse saber orgânico para a consciência do sujeito que se movimenta e para a sua autonomia por intermediação da língua e de outros signos não verbais. De acordo com Pignatari (1979), através da semiótica peirciana nos é possível estabelecer ligações entre códigos de diversas ordens ou entre linguagens diferenciadas. Para o autor ela permite ainda "ler" o mundo não-verbal, isto é, um quadro, uma dança, um filme, etc. e ainda ensina a "ler" o mundo verbal em ligação com o mundo não-verbal.

A semiótica pode ser genericamente definida como "ciência que tem por objeto de investigação todas as linguagens possíveis, ou seja, que tem por objetivo o exame dos modos de constituição de todo e qualquer fenômeno como fenômeno de produção de significado e sentido" (SANTAELLA, 2007, p. 15).

Ao determos em especificidade à discussão do processo gerativo de produção de significação - declinado aos sentidos produzidos pelo corpo ou os sentidos que ele atribui aos objetos - perspectivamos um olhar detido em estudos pautados no campo da semiótica. Este campo entende que os homens operam seus pensamentos ou constitui experiências por intermédio de signos, traços do real. É através destes torna-se possível estabelecer relações, interpretações e reproduções acerca de suas ações no mundo, mas também, como comanda a ordem fenomenológica, as ações do mundo sobre eles. Atualmente, a semiotização não se restringe apenas a textos e discursos, mas tem avançado para o nível dos objetos, das situações e das formas de vida. Portanto, podemos considerar que o corpo, qualquer corpo, pode ser semioticizado como texto, como discurso, como situação e forma de vida, expressão de um sentido fixado. Tais níveis são seguramente atravessados por uma "discursificação" e uma práxis dinâmicas envolvendo uma série de mecanismos e competências.

O objectivo da semiótica discursiva é o de fornecer uma base teórica e metodológica para a análise semiótica dos discursos sociais (verbais e não verbais) no contexto das práticas sociais em que têm lugar, analisa-los não para neles encontrar ou revelar o sentido, como quem engravatando a terra descobre um tesouro, porque esse sentido, seja o sentido de um texto seja o sentido de um corpo, 
existe somente como resultado de uma construção efectuada pelos sujeitos "em situação" (BÁRTOLO, 2007, p. 11).

A semiótica, essa ciência dos signos, nos remete ao entendimento do corpo como espaço aberto de construções de sentido, de devir. Possibilita-nos a realizar uma leitura particular através, de operadores e operações, dos modos de "ser" do corpo. As valências, de cada "corpo-objeto", são estabelecidas pela máquina que o produziu. As inúmeras máquinas semióticas (da economia, da medicina, da religião, do design...) faz por produzir corpo que se adequa a um determinado sistema em vigor entendido como sistema de produção. Trata-se, portanto, de "corpos paradigmáticos", enquadrados sob um determinado paradigma de saber. Os paradigmas são dinâmicos e são dependentes do campo de ação onde os mesmos atuam, dos modelos particulares construídos, na medida em que as explicações sobre um determinado corpo se transforma, transforma-se também as suas respectivas valências.

Ao entendermos o fenômeno do corpo, dos gestos, dos movimentos, das ações, dos comportamentos etc. como fato cultural, supomos apoio na semiótica, nos estudos dos signos seja a partir da necessidade de enfrentar os processos de mediação como imprescindíveis à produção do conhecimento, seja no sentido de se pautar uma epistemologia que se ocupe mais dos signos e da sua dinamicidade do que dos códigos instituídos pela nossa cultura. Assim, é compreendida como uma lógica interpretativa - apenas explicativa ou descritiva como supõe a fenomenologia - que nos permite perceber as mais diversas manifestações, inclusive as culturais.

Os aspectos empreendidos pela fenomenologia nesta perspectiva temática, subjugam-se na consideração da percepção como o lugar não linguístico onde se situa a apreensão da significação - esta que pressupõe a existência da relação. Partindo da leitura de Bártolo (2007) é possível afirmar que a influência de Merleau-Ponty para o projeto greimasiano estabelece a ruptura com a "linguística tradicional" atribuindo foco ao problema da significação. Assim, para o autor, a função semiótica passa a se centrar na questão do "corpo próprio" - conceito de raiz fenomenológica que Heidegger denominou de "corporeidade" e ocupa na semiótica o lugar atribuído a percepção - em que (corpo) não pode ser com propriedade nem sujeito, nem objeto, mas relação e condição de possibilidade desta (sujeito/ objeto). Nesta perspectiva ao corpo deve-se comensurar a preposição de uma existência dúbia de sujeito e um objeto, dois corpos concomitantes e entrelaçados vistos sob uma dupla perspectiva: ao mesmo tempo vivo e inerte, corpo que sou e corpo que tenho.

Meu corpo, dizia-se, é reconhecível pelo fato de me dar "sensações duplas": quando toco 
minha mão direita com a mão esquerda, o objeto mão direita tem esta singular propriedade de sentir, ele também. Vimos há pouco que as duas mãos nunca são ao mesmo tempo tocadas e tocantes uma em relação à outra. Quando pressiono minhas mãos uma contra a outra, não se trata então de duas sensações que eu sentiria em conjunto, como se percebem dois objetos justapostos, mas de uma organização ambígua em que as duas mãos podem alternar-se na função de "tocante" e de "tocada". Ao falar de "sensações duplas" queria-se dizer que, na passagem de uma função à outra, posso reconhecer a mão tocada como a mesma que dentro em breve será tocante - neste pacote de ossos e de músculos que minha mão direita é para minha mão esquerda, adivinho em um instante o invólucro ou a encarnação desta outra mão direita, ágil e viva, que lanço em direção aos objetos para explorá-los. O corpo surpreende-se a si mesmo do exterior prestes a exercer uma função de conhecimento, ele tenta tocar-se tocando, ele esboça "um tipo de reflexão", e bastaria isso para distingui-lo dos objetos, dos quais posso dizer que "tocam" meu corpo, mas apenas quando ele está inerte, e portanto sem que eles o surpreendam em sua função exploradora (MERLEAU-PONTY, 1999, p. 137).

A fenomenologia, um ramo da filosofia que debruça ao estudo deste "objeto" - ao estudo dos fenômenos - "ao dirigir-se diretamente para a essência do real procura ver a experiência como fenômeno, a partir dela mesma, e não a partir dos conceitos" (ALVARES, 2012, p. 48). Merleau-Ponty defendia a necessidade de a filosofia retornar ao mundo da vida, das coisas a fim de realizar um verdadeiro conhecimento partindo da vivência do sujeito (epistemológico), da vivência contextualizada do mundo que está a volta, este mundo de "meu corpo". Para tanto, efetiva um esforço no sentido de buscar "tornar visível e explicita a experiência vivida, a constituição do mundo-vida" (ALVARES, 2012, p. 48). Assim, é tarefa da fenomenologia revelar o mundo vivido.

Assim, neste campo, entender o fenômeno é ir até a essência da coisa, é vê-la a partir da sua própria realidade. O fenômeno não dissolve as ideias das coisas, são constituídas a partir de um único processo na medida em que ideias só existem porque são ideias sobre as coisas. Bueno (2003, p. 32) afirma que "o mundo passa a ser conteúdo do meu saber, o conteúdo da minha experiência, o conteúdo do meu pensar e o conteúdo da minha consciência”, e completa "a fenomenologia husserliana parte, pois, da vivência imediata da consciência para chegar a pressupostos do nosso conhecimento".

É salutar explicitar para o fato de que nem sempre o corpo, a corporeidade e a experiência sensível se fizeram objetos de estudo para este campo, a semiótica. Durante 
muito tempo ela foi vista como um método de análise do conteúdo, desta esperava-se que se denunciasse o sentido dos textos. Tal evolução, em relação ao seu objeto, têm se manifestado através da integração sucessiva dos "discursos enunciados" para uma semiótica das "situações", a qual antecipa a atual semiótica da "experiência sensível" que se preocupa em analisar a presença do homem no mundo enquanto portador e produtor de sentido.

De acordo com Bártolo (2007), tal evolução foi devida ao trabalho de Greimas, linguista lituano, que na década de 1960 empreendeu o lançamento de uma semiótica dentro do campo da fenomenologia. Essa fonte, em muitos aspectos, tem servido de inspiração nas pesquisas atuais mais avançadas, voltando-se novamente - redescobrindo a dimensão do "sensível" e da "estesia" - a presença do corpo e a mediação da percepção como lugar não linguístico onde se situa a apreensão da significação. As premissas constituídas sob a semiótica está para a compreensão de que o corpo é um ente que se encontra na ordem da significação e, neste sentido, é capaz de desenvolver análises e processos intencionais de produção de sentidos do corpo e da sua instrumentalização, interessando-nos a entender como o corpo a ser operado e como essa operação é discursiva e inter-relacional.

[...] o corpo é ao mesmo tempo o sujeito e o objeto das representações. $\mathrm{O}$ que eu sinto, o que aprendo, o que memorizo, todas as sensações, percepções e representações interferem nas imagens de meu corpo, que é simultaneamente a possibilidade e a condição daquilo que experimento e de minhas maneiras de interpretar o que eu experimento (JEUDY, 2002, p. 20).

Exigir a descoberta do sentido é uma tarefa que não se pode exigir a semiótica, mas apenas e tão somente a significação. "Aqueles que encontraram o sentido da vida aparentemente estão mortos", afirma Bártolo (2007, p. 37). Assim, a tensão semiótica não se funda em apontar o real das coisas, na verdade, o real é o que se faz sentir, o que "se faz sentido". Segundo o mesmo autor a diferença entre sentido e significação é análoga à distinção entre ser e parecer.

A semiótica estuda a significação na medida em que ela se ocupa do parecer, do poder-ser do sentido. Assim é relativamente uma semiótica do corpo, ela consistirá, no estudo dos processos a partir dos quais é enunciado um poder-ser do sentido do corpo (BÁRTOLO, 2007, p. 39).

Embora a semiótica possua tantas afinidades com a fenomenologia temos que relevar que se trata de abordagens distintas, não sendo, portando, plausível diluir a semiótica na fenomenologia ou vice versa. As diferenças 
estão interpostas na ideia de que para a semiótica o sentido não se encontra "nas coisas" como supõe a fenomenologia, mas antes é resultado da sua colocação em forma, da relação entre um observador competente e o sentido como "alvo".

Alvares (2012) pontua que, para Merleau-Ponty (1999), o sentido de uma coisa habita a própria coisa, o sentido não é uma ideia que organiza e ordena os aspectos sensíveis. Assim,

Apreender o sentido da coisa não é um ato do espirito, mas um ato do corpo. A coisa se mostra, revela seu ser pela própria organização de seus aspectos sensíveis. Por meio da fenomenologia, o sensível recebe um estatuto diferente daquele postulado pelo empirismo clássico e pelo racionalismo. O sensível passa a ser compreendido enquanto território instituidor da experiência humana (ALVARES, 2012, p. 117).

A semiótica postula que o sentido não está "nas coisas" [...].Há uma relação de pressuposição que se estabelece entre o surgimento de uma "existência" (a do sentido) e o exercício de uma competência (a do sujeito): o semiótico competente faz ser sentido. O sentido releva de um acto (para a semiótica só há sentido em acto, só há fazer sentido na medida em que no corpo-a-corpo entre um sujeito e um objeto o sujeito o faz ser, enunciando-o), construção dinâmica, geratividade. Nisto distingue-se o "olhar semiótico" do "olhar fenomenológico": o sentido longe de ser apreendido ou recebido, é pensado como resultando de um acto semiótico gerador (BÀRTOLO, 2007, p. 41).

A perspectiva pela qual o presente ensaio se debruça, pauta-se na crença de que o sentido é construído a partir de enunciações, intencionalidades, ou seja, estruturas elementares de significação formada a partir desta dinâmica, fruto das inter-relações, dois a dois, corpo-a-corpo, carne envolvida na carne do outro. O sujeito "faz ser" o sentido em ato.

Para a semiótica de Peirce (e aqui pode-se perceber mais explicitamente sua base fenomenológica) existem três modos de ser ou categorias da experiência, presentes em todo fenômeno, são elas: Primeiridade (Sensação), Secundidade (Percepção) e Terceiridade (Compreensão).

O nível mais elementar e imediato da experiência corporal humana pode ser denominado de Primeiridade, na linguagem comum é possível designá-lo de nível das sensações corporais. Na primeiridade estão implícitas as noções referentes à aparência, tal como elas aparecem, sem qualquer sentido de começo, fim ou continuação. Implica as noções de possibilidade, qualidade de sentimento, 
diversidade, acaso; também às experiências instantâneas, incondicionais, espontâneas, desprovida de qualquer análise ou comparação. Experiência marcada pela sua pura qualidade, antes que se manifeste qualquer relação com outra coisa (emoções, comparações causa-efeito etc.).

O segundo nível da experiência é chamada de Secundidade que na linguagem comum pode ser chamada de percepção. Podemos dizer que nesse caso a sensação, primeira, se apresenta para a mente como um objeto definido. É uma experiência direta, não mediatizada; envolve uma consciência bilateral, imediata, de dualidade bruta entre duas coisas; de alteridade; implica as noções de existência, resistência, conflito, choque e reação entre eu e não-eu, de aqui-agora, etc.

E por fim, a Terceiridade é fase que cria um novo signo mais complexo, mais desenvolvido ou não estabelecendo relações com a sua realidade, isso ocorre quando a ação da mente, que na prática são raciocínios expressos sob proposições linguísticas - frases ou argumentos -, passam pelos níveis anteriores da experiência corporal e cognitiva humana. Em outras palavras, na Terceiridade implica as noções de generalização, hábito, lei; é a experiência que ao fazer a mediação entre duas coisas, traduz-se em apenas uma formando uma síntese, uma consciência sintetizadora.

Sendo assim, a complexidade dos três níveis da experiência, acima indicados, pode ser sintetizada na seguinte proposição formulada por Peirce (1990, p.46):

Um signo, ou representamen [sensação de uma qualidade primeira], é aquilo que sob certo aspecto ou modo, representa algo para alguém [um signo na mente, que em relação ao signo primeiro, aparece em segundo lugar]. Dirige-se para alguém [esse signo segundo ligado ao primeiro], isto é cria na mente desta pessoa, um signo equivalente, ou talvez um signo mais desenvolvido [esse último signo é fruto da especulação retórica e sugestiva que apenas o ser humano pode produzir].

Os processos de mediação, indispensáveis à produção do conhecimento, é conceituada por Peirce (1990) como representação no sentido de se colocar no lugar de, de estar numa tal relação com outro, como se fosse o outro, e não no sentido da réplica ou da imitação.

[...] uma coisa que representa uma outra coisa: seu objeto. Ele só pode funcionar como signo se carregar esse poder de representar, substituir uma outra coisa diferente dele. Ora, o signo não é o objeto. Ele apenas está no lugar do objeto. Portanto, ele só pode representar esse objeto de um certo modo e numa certa capacidade [...] (SANTAELLA, 2007, p. 12). 
Neste sentido, para o autor, qualquer coisa pode se tornar signo, desde que seja estabelecida a relação entre três elementos, são eles: O Representante, o Objeto e o Interpretante.

O Representante (um sentimento, uma sensação, certo som, certo gesto, etc.), o Objeto (aquilo que o signo re-presenta) e o Interpretante (a relação de "equivalência" criada entre os dois elementos anteriores por uma mente interpretadora. É importante esclarecer que o interpretante não se refere a uma pessoa ou ser (que seria o intérprete), mas ao signo/pensamento interpretante (BETTI, 2007, p. 2012).

Diante disso, pode-se considerar que a produção do signo (semiose) é conferida entre a relação de representação entre o signo e seu objeto, por intermédio do interpretante. Em outras palavras, pode-se afirmar que o interpretante é a categoria que possibilita a mediação entre o real e a consciência, na medida em que a representação, de acordo com Ferrara (1981, p. 75), "é o processo cognoscente pelo qual o sujeito possui e produz signos, sua única possibilidade de mediação com a realidade, a única maneira que possui de conhecer os fatos concretos, a realidade material e de conviver com ela". É por este, e outros sentidos, que Peirce, afirma que a produção do conhecimento é sempre uma produção de signos:

[...] o pensamento é signo - e o significado de um signo é sempre um outro signo, pois o interpretante, ele mesmo, é um novo signo, de tal forma que o fluxo de pensamento dá-se em um fluxo incessante de signos, já que a mente humana trabalha com associações ininterruptas, ad infinitum (BETTI, 2007, p. 203).

Diante disso, por compreender que o processo de produção de signos - a linguagem - é a raiz da produção do conhecimento, como afirmamos no início deste capítulo, é que agregamos a semiótica de Peirce como ferramenta qualificadora e privilegiada para "ler" - interpretar signos inusitados, novos e imprevistos, além dos já institucionalizados e/ou codificados - entre os mais diversos campos e práticas socioculturais diversas. Pignatari (1979) afirma que a semiótica de Peirce encerra de vez a ideia de que só é possível se atribuir significado as coisas quando traduzidas em palavras quando o processo de semiose é capaz de associar e encadear signos de diversos tipos. Ora, se tudo é signo, como vimos, a hierarquia entre "verbal" e "não-verbal", "intelectual" e "corporal" é abolida. Para a Educação, de modo geral, tal ideia confere um ganho qualitativo gigantesco na medida em que intercepta a possibilidade de os sujeitos estabelecerem novas relações interpretativas interpeladas sobre diversas óticas e ordens. 
Desta forma, na perspectiva semiótica, o "aluno" é compreendido como produtor de signos e o "professor" um intermediário, um interlocutor que possibilita a efetivação das relações semióticas. Sendo assim, cabe ao professor a função de apresentar as diversas possibilidades, "quase-signos", por um lado, e por outro auxiliar, como propõe Betti (2007, p. 205) "na articulação da trama das relações interpretantes estabelecidas pelos alunos, sugerindo-lhes, conforme o efeito que se busca (estético, ético ou lógico), interpretantes que possam ser incorporadas ao fluxo de signos".

Contudo, deve-se considerar o corpo em sua variação de gestos, movimentos e expressão, como signos, sendo este o primeiro dos principais desafios para a educação. $\mathrm{Na}$ perspectiva fenomenológico-semiótica as relações comunicativas são bastante relevadas, principalmente quando tratamos da relação professor-aluno. Nesse sentido, é que a educação, vista como intervenção denotada sobre a visão de intenção autoritária, precisa ser repensada, precisa ser vista como espaço de inter-locução (diálogo), de inter-pretação, no sentido de se propor a ampliar possibilidades para que os alunos estabeleçam relações interpretantes.

Assim, a Performance Art, instrumento de proposição neste ensaio, como linguagem artística, oferece-nos possibilidade para realizar uma leitura ou uma construção semiótica no postular ou no desenvolver de suas ações. Esta manifestação artística contemporânea propõe em seu leito outra leitura e construção de sentido do corpo fora daquela constituída tradicionalmente. A Performance, ao possibilitar inúmeras formas de organização sígnica para compor seu cenário, opera por intermédio do corpo e constitui um discurso, uma representação do que almeja transmitir, comunicar. O performer, como uma espécie de semiólogo, utiliza intencionalmente o seu corpo, manipula os códigos que lhes são oferecidos e propõe uma forma de experiência.

O performer institui um objetivo, ele cria, articula, dita a forma pela qual o espectador vai recepcionar essa experiência e esta é dada pelo modo que ele organiza a matéria bruta que possui. A arte é uma produção da mente. Os signos, nada mais são, neste caso, faculdades a priori impregnadas no corpo. Os signos, como âncoras, são partes do próprio corpo que encena, que se espetaculariza na ação.

\section{A PERFORMANCE ART: O CORPO E SUAS REPRESENTAÇÕES SIGINICAS}

As coisas não são diante de nós simples objetos neutros, que contemplaríamos; cada uma delas simboliza para nós uma certa conduta, lembra-las provoca reações favoráveis ou desfavoráveis; é por isso que os gostos de um homem, o seu caráter, a atitude que tomou a respeito do mundo e do ser exterior, se leem nos objetos com que escolheu rodear-se, 
nas cores que prefere, nos lugares de passeio que escolhe.

Merleau-Ponty (1999)

A Performance Art é uma corrente artística reconhecida na década de 1960, embora apenas consolidada como prática e linguagem artística nos anos de 1970. Desde o início do século XX, a arte e seus parâmetros tradicionais vinham sendo questionados, e neste sentido, as ações performáticas primitivas (protoperformances) foram utilizadas como forma de comportar a necessidade de romper com as proposições artísticas vigentes apontando possibilidades de se criar e de perpetuar novas formas de arte. Encontrando-se alocada, inicialmente, no seio das artes plásticas/visuais, artistas pictóricos, que antes se limitavam a registrar suas criações sob a superfície da tela, passaram a valorizar o momento de criação o que prenunciava uma mutação na arte contemporânea.

Com um grande potencial de valor crítico, a Performance pode ser entendida como uma fusão de gêneros que emerge dos movimentos de vanguarda (Futurismo, Dadaísmo, Surrealismo etc.) como uma forma de provocação e desafio na busca de um rompimento com a arte tradicional. A arte contemporânea e a Performance como linguagem partícipe de um contexto histórico-cultural "caótico" estabeleceu-se aberta à articulação de diferentes modalidades e formas artísticas sob o viés da interdisciplinaridade - na medida em que incorpora em suas obras técnicas do teatro, da mímica, das danças, da fotografia, da música e do cinema. Essa abertura e diálogo entre as diferentes formas colocou em cheque os enquadramentos artísticos e sociais anteriores (tradicionais) na tentativa de romper com as barreiras e hierarquias pautadas entre arte e "não-arte".

Todas as propostas que percorreram a sua trajetória histórica (Happening, body art, live art, etc.) até chegar à performance propriamente dita, tinha como denominador comum a desfetichização do corpo, ou seja, romper com a exaltação da beleza elevada durante séculos pela literatura, pintura e escultura a fim de trazê-lo à sua função de instrumento do homem. Em outras palavras, a Performance se constituiu em uma atividade cujo objeto/produto é o mesmo que geralmente se utiliza como instrumento. O corpo, nesse sentido, sugere a sua participação como guia no processo de criação e como produto artístico. O corpo passa a estar no centro das proposições artísticas exigindo novas conexões nas formulações conceituais.

Performance, como arte, é um campo de linguagem, comunicação, expressão, significação... É fronteira e ruptura, é ação, é corpo presente. Glusberg (1987) afirma que toda ação humana é, particularmente, corporal e sendo o corpo a mais plástica e dúctil das matérias significantes, “expressão biológica de uma ação cultural”, a performance é, para o autor, considerada um campo por excelência de realizações semióticas. 
Para Bártolo (2007, p. 82), “o corpo que abraçamos, o corpo que estudamos, o corpo que vemos envelhecer, o corpo que adoece, é um corpo integrado no plano do discurso, um corpo lógico, semio-lógico". Ora, os processos de significação oriundos das condições sensíveis necessárias para conhecer a realidade possível de um objeto perpassam sob a constituição de uma estrutura racional por meio de sistemas elementares (signos) ora organizados e classificados no transcurso dessa experiência fazendo tornar o objeto cognoscível. Sem operacionalização, sem estruturação sígnica é impossível apreender os sentidos do discurso, é impossível ocorrer experiência sem preposição (signos), sem enunciado.

Entre formas distintas de organizar as experiências por meio da concatenação sígnica, torna-se, portanto, possível e necessário transcender o pensamento sobre a aprendizagem destituída à educação em seu lugar costumeiro de campo do saber, qualquer lugar é lugar de relação, de troca simbólica. Qualquer lugar é lugar de experiência, de educar e ser educado. Se aprender supõe a organização de signos e apreensão de seus sentidos por que não atribuí-las de outras formas, formas não convencionais? Por que não vivenciar um conteúdo dentro da sua própria realidade (a performance não se desliga ao amplo âmbito sociocultural)? Por que não aumentar o campo das relações da experiência (qualquer espaço é espaço para se fazer performance)? A performance pode ser considerada como a via de uma desconstrução pois, é rompimento de alguns paradigmas, de dogmas, de desnaturalização do naturalizado. É reflexão, crítica, construção, transformação, educação, transgressão.

O corpo na performance é um discurso, um texto a ser lido, sentido e interpretado, semioticizado. O artista/ performer se apodera de códigos, opostos aos das convenções tradicionais, os articula e os domina a fim de representar algo que se quer dizer sem se ater ao que as coisas realmente são. A cultura impõe uma certa codificação a determinados processos corporais, naturaliza alguns gestos e atribui alguns significados fixos a determinadas ações cotidianas. O corpo e o seu comportamento estão submetidos a regras e a normas sociais, no entanto, o performer também é um ativo manipulador de códigos, confere a possibilidade de ressignificações (agregação de novos significados) submetendo seu discurso em oposição aos dogmas interpostos. Embora este parta das linguagens tradicionais ela faz por colocá-las sempre em conflito.

Derivante a esta multiplicidade de sistemas semióticos desenvolvidos pela sociedade, Glusberg (1987) afirma que o discurso do corpo é, talvez, o mais complexo modo de discursar, e isso explica as dificuldades em reter sua dinâmica e seu desenvolvimento característico. Desmitificar a ordem cultural para re-converter o corpo em signo é a operacionalização mestre da arte, afinal, como dito, na nossa cultura os atos fundados no corpo se tornaram tão naturais/habituais que nós já não mais reconhecemos um 
gesto como um ato do dia-a-dia cabendo ao artista bastante esforço ao pretender tornar essa prática de ordem necessária. Em outras palavras, a Performance além de uma proposta artística, se posiciona em questionamento ao natural/habitual, coloca em crise dogmas - principalmente os comportamentais - seja mediante a simples ironias ou de referências sarcásticas.

Sendo assim, estamos em convergência a um fator que é desalienante nesta linguagem: a perda de cisão e maniqueísmo teórico. Mesmo sobre as constantes indagações e constatações de que o corpo é matéria moldada por fatores externos, pelos padrões socioculturais e não fonte de origem de seus comportamentos, a performance opera em função de uma ruptura perturbadora propondo uma nova retórica, uma nova forma de ler e enxergar os fatos. Talvez, dessa forma, desague um desconcerto ou indiferença - e até em temor e repulsa - ao depender da infraestrutura, do sistema de comunicação que estar suportar as novas propostas artísticas.

O desenvolvimento de uma ação com o corpo, na arte - sendo as figuras linguistas insuficientes para transpor acontecimentos visuais que possam dar conta da complexidade do corpo e de seus comportamentos - demanda, por um lado, uma perspectiva multidisciplinar e uma concepção de retórica que é totalmente diferente da tradicional: uma retórica da ação e do movimento, afirma Glusberb (1987). Segundo o autor, "este ponto de vista estilístico é de fundamental importância para uma aproximação do fenômeno da arte e do corpo, caso contrário há o perigo de cairmos na superfície da crítica impressionista ou da trivialidade descritiva" (GLUSBERG, 1987, p. 64).

Pautar tais relações entre corpo-arte é, por essência, de fundamental importância. Primeiro, as ações corporais nas performances instituem um contato direto entre emissor-receptor sem intermediações técnicas, como equipamentos eletrônicos modernos, o que faz eliminar os significados que os meios de comunicação agregam particularmente aos conteúdos que transmitem. Assim, a experiência da proximidade, do contato corpo-a-corpo, carne na carne, a força de transmissão de atitudes comportamentais não se mostram sobrecarregados por elementos de outra espécie levando-nos à conclusão de que existe, nesta relação dinâmica, um complexo processo de sintagmas a serem significados a partir de todos os canais da percepção, tanto de forma alternada, quanto simultânea. Como dito, o corpo é um produto semiótico. O corpo nu, o corpo vestido, as transformações que podem operar-se nele, são exemplos das inúmeras possibilidades que se oferecem a partir do simples, do imprevisto trabalho com o corpo. "O semiólogo opera, em certo sentido, como o anatomista, só conhece o que analisa e o processo de análise é, sempre, um processo de construção do objeto que se tem diante dos olhos (BÁRTOLO, 2007, p.107). A performance procura transformar o corpo em um signo, em um veículo significante e 
a semiótica enquanto decodificadora das ações, dos movimentos, dos comportamentos das distâncias, coloca simultaneamente o espectador no tempo próprio do artista.

Deve-se considerar que o performer não é apenas um agente que põe em ação os sentidos, ele também produz significados, atua como um observador, na realidade, ele observa a sua própria produção ocupando um duplo papel de protagonista e receptor do enunciado (a performance), ele possui um papel ativo e consciente de suas funções.

De acordo com Glusberg (1979), para que haja a conversão do objeto em signo a fim de provocar no espectador, mediante a re-codificação uma expectativa, é necessário que quem o utilize simultaneamente o observe. Assim, o mecanismo da mimesis, substituído ao nível da performance, é transportado para o público. A re-significação nasce de ações, que vão dar significado umas às outras, como um processo anafórico, criando uma intra-semiose na medida em que as relações que se estabelecem entre os signos pertencem a mesma sequência.

Sobre o ponto de vista temático, diferentemente do teatro, da literatura, etc. a performance não privilegia temas a serem trabalhados. Performance e performers encontram-se inteiramente ligados e associados ao conjunto e as condições sócio-contextuais. Nesse sentido, a sociedade desempenha um papel importantíssimo, ela oferece por si uma pluralidade temática que confere ao artista uma liberdade de escolher diferentes formas de expressão facilitando, deste modo, o seu desenvolvimento numa dinâmica singular e de maximização da liberdade.

Para Bártolo (2007), a linguagem em si não tem intencionalidade. É o discurso, não a linguagem, que decide o "regime de linguagem". O discurso do corpo, assim como qualquer outro ato comunicacional, produz sintagmas através de seleções sucessivas de paradigmas. Enquanto, os demais processos de comunicação se utilizam de uma seleção restrita, finita, fechada de sintagmas, nas performances o paradigma é aberto, diverso, rico. Sendo assim, o performer pode trabalhar com vários códigos ao mesmo tempo - códigos que também são governados pela mobilidade e mudança permanente -, estes determinarão na sua interação, possibilidades combinatórias diversas. O performer, neste caso, trabalha como operador de códigos é um operador de transformações de inumeráveis códigos e emana um conjunto de mensagens compostas por signos móveis fundamentados em tais paradigmas. A eficácia do performer se fundamenta, então, no uso que se faz dos códigos abertos que dão a ele liberdade de expressão gestual ou comportamental.

Por intermédio das novas variantes simbólicas é possível conscientizar sobre a possibilidade de idealizar o corpo como um produto semiótico, ou seja, seu discurso natural, e como efeito de uma infraestrutura simbólica, deve-se construir uma forma discursiva suscetível de ser decodificada e interpretada. 
O performer é, simultaneamente, agente e ator de sua performance, é ativo e manipulador de códigos. Ora, não há Performance sem contexto, sem intenção, sem consciência, sem organização, sob os quais também não há experiência. A consciência do performer transcende a organização de uma Performance, colocando de forma clara as condições em que o trabalho foi produzido. Embora possua uma grande abertura para a imprevisibilidade a concepção da performance sem um objeto vai pressupor a sua descontextualização, que não é o caso.

Sendo assim, as exigências do meio social permeada pelo percurso da história têm adequado as formas de utilização do corpo, que ao depender de cada organização, impõe limites a seus membros. A utilização do corpo como forma de expressão artística vem questionar e propor diversos tipos de reflexões, inclusive as que estão na base histórico-cultural. A performance, em sua linguagem que é própria do discurso contemporâneo, resgata um pouco da história na medida em que ao rejeitar o estereótipo corporal que, ora sobreposto, resgata as mais diversas formas de utilizar, de ver, de expressar o corpo, possibilidades estas que são alimentadas ou não a partir da cultura e da sociedade a qual fazemos parte.

As relações do homem mantidas com o seu corpo foram praticamente estáveis em cada período. Na contemporaneidade e nas performances tal estabilidade, que antes representava identidade e segurança, vai ser rompida, quebrada convertendo-se num elemento perturbador. Ora, nem todos os gestos e movimentos são identificáveis, nem toda transformação é imediatamente suscetível a uma leitura. A transgressão dos modos convencionais coloca em crise os aparatos culturais e desmascara as funções reguladoras.

Na história da arte, até o momento, o corpo tomou parte do espetáculo. Hoje ele é o próprio espetáculo. O corpo se abre para ser visto de formas diferentes das habituais, o corpo é matéria significante, logra significados múltiplos que se ligam em contextos artificiais, construídos, arquitetados humanamente/simbolicamente. A naturalidade se esvanece em duplo sentido, seja pela via do contexto (a cenografia), seja pela do texto (o corpo). O corpo é um produto semiótico e seu discurso natural e, como efeito dessa infraestrutura simbólica, deve-se chegar a uma forma de discurso suscetível de decodificação e de interpretação, fato este que se liga aos instrumentos de conhecimento, correlatos ao que se sucede na história do pensamento humano. O texto, o discurso para ser lido exige-se uma nova postura do receptor, menos preconceituosa, mais vidente.

Voltar ou ir ao encontro do corpo? As proposições artísticas e educativas mais contemporâneas tendem a reivindicar, cada vez mais, o pleno valor do corpo humano frente a sua capacidade de produção de signos fazendo do corpo meio e objeto por excelência de manifestação e rupturas com: 1) a ideia preconceituosa de uma codificação 
externa e convencional; 2) as artes corporais tradicionais, como a dança, se diferenciam desta arte corporal distinta; 3) as concepções éticas e morais, acerca do corpo como prisão da alma; 4) o espectador que é confrontado com uma minuciosa investigação dos ritmos internos do corpo, de seus tempos vitais e das relações que o artista mantém com sua própria biologia; 5) uma nova retórica que transgride a velha codificação do corpo instrumento de manifestação artística.

\section{CONSIDERAÇÕES FINAIS}

O presente ensaio para além do seu objetivo principal buscou ponderar relações teóricas no sentido de propor uma ampliação e superação das perspectivas que ainda se encontram pautadas de forma dominante acerca das formas de conceber o corpo.

Aqui o corpo foi discorrido não sob o ponto de vista mecanicista, do modelo de "corpo-máquina" oriundo da cultura da dissecação, mas um espaço onde se ancoram os sentidos em realização constante de significações necessárias a vida, fruto, produtor e projetor de uma cultura. Trata-se de um corpo que não se identifica apenas com físico, com a carne, nem se assemelha ao corpo de uma coisa, de um objeto. O corpo é base para toda e qualquer experiência, das possibilidades de sentido e de significação a como visto este foi aqui apreendido sob alguns aspectos da semiótica e da fenomenologia - que a crença de que o lugar do conhecimento é no corpo do indivíduo, ou seja, a extensão cognitiva do sujeito se constrói sempre sobre este substrato corporal, através da experiência e da linguagem. Compreende-se que a vivência do saber, a experiência a qual se propõe está diretamente ligada aos processos de significação intrinsecamente associados à produção de sentidos.

Portanto, destacamos a necessidade de os processos educacionais assumirem a função de auxiliar na mediação simbólica desse saber orgânico para a consciência do sujeito que se movimenta, e para a sua autonomia, por intermediação da língua e de outros signos não verbais. A Performance Art - vista como um instrumento de organização sígnica/propedêutica -, neste sentido, se incumbiu de operar por intermédio do corpo a construção de um discurso, uma representação do que almejou-se transmitir, comunicar.

Contudo, relevar o corpo em sua variação de gestos, movimentos e expressão, como signos, sendo este o primeiro dos principais desafios para a Educação. Estas, vista como intervenção denotada sobre a visão de intenção autoritária, precisa ser repensada, precisa ser vista como espaço de inter-locução (diálogo), de inter-pretação, no sentido de se propor a ampliar possibilidades para que os alunos estabeleçam relações interpretantes. Os signos, como âncoras, são partes do próprio corpo que encena, que se 
espetaculariza na ação. Há sempre algo está predisposto na arte, apesar de ser pega pela liberdade de fruição estética, não é completamente improviso, acaso. Assim, propomo-la como ferramenta de manifestação por excelência, como plataforma de aprendizagem, de significação de conteúdos, de formas de ser e dar sentido aos objetos, as coisas ou ao próprio corpo que é o cerne da sua ação e da sua reflexão.

\section{REFERÊNCIAS}

ALVARES, S.C. Educação estética na EJA: a beleza de ensinar e aprender com jovens e adultos. São Paulo: Telos, 2012.

BÁRTOLO, J. Corpo e Sentido - Estudos Intersemióticos. Coleção Estudos em Comunicação. Livros Labcom, 2007.

BETTI, M. Educação Física e Cultura Corporal de Movimento, uma perspectiva fenomenológica e semiótica. Revista da Educação Física/UEM, Maringá, v. 18, n. 2, p. 207-217, 2. sem. 2007.

BUENO, E. R. de A. Fenomenologia: a volta às coisas mesmas. In: PEIXOTO, Adão José. (Org.). Interações entre fenomenologia e educação. Campinas: Alínea, 2003.

DUARTE JÚNIOR, João Francisco. Fundamentos Estéticos da Educação. São Paulo: Cortez, 1981.

FERrARA, L. D. A estratégia dos signos. São Paulo: Perspectiva, 1981.

FERNANDES, U. J. F. A raiz no mundo: uma arqueologia do conceito de corpo próprio em Merleau-Ponty. 2003. 150f. Dissertação (Mestrado em Filosofia) - Programa de pós-graduação em Filosofia, Universidade Federal de Uberlândia, Instituto de Filosofia, 2013.

GLUSberG, J. A arte da performance. São Paulo: Perspectiva, 1987.

. Arquitectos de Buenos Aires. Buenos Aires: Editora Espacio, 1979.

IBRI, I. A. Kosmos Noetós: a arquitetura metafísica de Charles S. Peirce. São Paulo: Perspectiva, 1992.

JEUDY, H-P. O corpo como objeto de arte. São Paulo: Estação Liberdade, 2002.

MEDEIROS, Rosie Marie Nascimento de. Body Art e existência: o conhecimento do corpo na Educação Física. In: NÓBREGA, Terezinha Petrucia da. (Org.) Escritos 
sobre o corpo: diálogos entre arte, ciência, filosofia e educação. Natal: EDUFRN - editora da UFRN, 2009.

MERLEAU-PONTY, M. Fenomenologia da percepção. Tradução de Carlos Alberto Ribeiro de Moura. 2 ed. São Paulo: Martins Fontes, 1999.

PEIRCE, C. S. Escritos coligidos. São Paulo: Abril Cultural, 1978.

Semiótica. 2. ed. São Paulo: Perspectiva, 1990.

PIGNATARI, D. Semiótica e literatura: icônico e verbal, oriente e ocidente. São Paulo: Cortez \& Moraes, 1979.

SALATIEL, J. R. Peirce e Kant sobre categorias: parte I - Dedução metafísica e reviravolta semiótica. Cognitioestudos: Revista Eletrônica de Filosofia, São Paulo, V. 3, n.1, p. 79-88, jan/jun, 2006.

SANTAELLA, L. Comunicação e semiótica. São Paulo: Hacker, 2004.

2007.

O que é semiótica. São Paulo: Brasilense,

SANT'ANNA, D. B. Políticas do corpo: elementos para uma história das práticas corporais. São Paulo: Estação Liberdade, 1995 .

SILVA, A. M. Corpo, ciência e mercado: reflexões acerca da gestão de um novo arquétipo da felicidade. Florianópolis: Editora da UFSC, 2001.

ZOBOLI, F. Cisão corpo/mente: espelhos e reflexos nas práxis da Educação Física. São Cristóvão: Editora UFS, 2012. 